\section{Stigma, deforming metaphors and patients' moral experience of multibacillary leprosy in Sobral, Ceará State, Brazil}

\author{
Estigma, metáforas deformadoras e experiência \\ moral de pacientes com hanseníase multibacilar \\ em Sobral, Ceará, Brasil
}

Marilyn K. Nations 1,2

Geison Vasconcelos Lira ${ }^{3}$

Ana Maria Fontenelle Catrib 1

\footnotetext{
${ }^{1}$ Centro de Ciências da Saúde, Universidade de Fortaleza, Fortaleza, Brasil. 2 Department of Global Health and Social Medicine, Harvard University Medical School, Boston, U.S.A. 3 Faculdade de Medicina, Universidade Federal do Ceará, Sobral, Brasil.

Correspondence M. K. Nations Department of Global Health and Social Medicine, Harvard University Medical School. 641 Huntington Avenue, Boston, Massachusetts, U.S.A 02115. nations@unifor.br
} 
Known as the "illness of untouchability" in the ancient Indian Caraka Samhita medical text, it is attributed to moral transgressions: "untruthfulness", "sinful acts", and "blasphemy against the gods" 6. In Pakistan, leprosy-affected "sinners" are abandoned by spouses, divorced, expulsed from villages, left to beg on city streets and confined to animal quarters 5. Even the 1981 introduction multi-drug therapy (Dapsone, Clofazimine and Rifampicin) - highly effective against both paucibacillary and multibacillary disease forms - has not eradicated leprosy's stigma 5,6. As with infectious cholera 7, popular resistance to control is subliminal, albeit strong 5,6 . Some $30 \%$ of Pakistani patients dropped-out of multidrug therapy; $54 \%$ denied ever having leprosy or proclaimed themselves "cured", prompting Mull et al. 5 (p. 805) to declare that: "clearly 'non-compliance' relates to the stigma attached to 'lepers', together with the common idea that equates leprosy with deformities".

Brazil - second behind India in newly detected cases - reports a high prevalence of Hansen's disease (4.6/10,000 inhabitants in 2001), climbing to $6.13 / 10,000$ inhabitants in the Northeast 8 . While poverty, inequality, urbanization, low educational level and food shortage are known risk factors in Ceará State 9, stigma's influence is unknown. Qualitatively, however, the Portuguese word lepra (leprosy) is synonymous with grotesque deformities. The derogatory term leproso (leper) labels anyone ostracized by society. Even thirty years after its official name change to stigma-free Hansen's disease (hanseníase), lepra's pejorative connotation persists 10 . Queiroz \& Puntel 11 report that $50 \%$ of $M$. leprae-affected in Campinas, São Paulo, Brazil, distinguish between the two terms, considering them separate diseases or different stages of the same disease - lepra the most severe. Depression, sexual impotency and suicidal thoughts are reported and dermatological symptoms are disguised as "sun" or "pregnancy spots"; informants avoid kissing children and spouses and separate their utensils 11,12. In São Paulo, women with leprosy, when compared with men, are more often single, separated or divorced, live with family and children rather than husbands or partners, reside at the same address for a shorter duration, work in domestic occupations without benefits, have less education and attend religious cults $13 ; 37.1 \%$ reject multi-drug therapy. Leprosy, by all accounts, is a demoralizing disease.

\section{Social theories of stigmatization}

Social scientists have investigated stigma since the 1960s, yet disagree on theoretical approaches. Early classics emphasized the origin of stigma as an intersubjective, psychological process. Goffman ${ }^{14}$ postulated that stigma occurs when the construction of categories is linked to stereotyped beliefs that label and distinguish people as different or unacceptable. They either resist stigmatization with cover-up strategies or internalize a negative self-perception, "spoiling" identities and reputations. British anthropologist Douglas 15 argued that stigma is symbolically constructed when personal identities are associated metaphorically with "impure" images - raising doubts about his/her integrity, honesty, sexual purity, etc. - "polluting" the moral essence of personhood. In Hong Kong, patients in treatment for schizophrenia were reportedly stigmatized by structural discrimination - inequitable health policy, resource allocation and service organization which privilege service providers' control over users 16. In a Brazilian shantytown, poverty, class disparity, police violence, and militaristic interventions shape and signify cholera stigma for infected residents 7 .

Studies of leprosy stigma have continued to target cognitive processes of infected individuals 17,18. Exceptionally, Opala \& Boillot 19 report that among the Limba of Sierra Leone, Africa, stigma varies according to social context and access to effective therapy. Stigma is severest and unresponsive to medications when onlookers view the "leper" as morally corrupt and fear both the individual and the disease 19. The Limba's various interpretations of leprosy stigma, within a single culture, suggests it is multivocalic ${ }^{20}$. Indeed, stigma is complex and, we suspect, at the heart of leprosy in Northeast Brazil. How structural forces shape its moral experience in this poor, tropical setting is unclear. Through patients' voices, we aim to reveal the semantic network 20 of lepra in an endemic community.

\section{Methods}

\section{Status-conscious Sobral, Ceará, Brazil}

Sobral, a town of approximately 200,000 inhabitants situated in the desert backlands (sertão) of Ceará State in Northeast Brazil, serves as an excellent locale for the investigation of stigma because of its rigid social structure, high prevalence of Hansen's disease, model Family Health Program (FHP), and political mandate to eradicate the disease. Located $250 \mathrm{~km}$ from Fortaleza 
(the state capital with a population of nearly 2.5 million), the remote town is jokingly nicknamed "The-United-States-of-Sobral", owing to its residents' audacious, First World "triumphant posture" (sobralidade triunfant) ${ }^{21}$. Not without reason. The town proudly traces its nobility to Portugal's King, who christened it "The Distinct Royal Village of Sobral” - a settlement of European nobility on Brazilian soil 21. Reminders of its regal past adorn the town: the aristocratic symbols decorating the city's flag, a replica of France's Arc de Triomphe, and scores of ornate Catholic churches. However life, today, is harder and hungrier: $54.8 \%$ of adults are unemployed and $79 \%$ of household heads earn less than US\$166/ month, falling to less than US\$ 83/month on the city's outskirts ${ }^{22}$. Traditional families - the ruling elite - dominate local politics. Armed landowners, known as coronels, impose "order" through threats and violence. A Second District Judge was condemned in 2005 to 15 years in prison for murdering an unarmed night watchman at Sobral's Lagoa Supermarket - a horrific crime captured on film by security cameras 23 . Wives suffer domestic violence, an epidemic in Ceará's interior, where 118 women were murdered in 2005 alone, most by intimate partners 24 . In this authoritative, top-heavy, and hierarchically-structured system, ordinary citizens seek status and upward class mobility emulating First World trends. Imported motorcycles race through cobblestone streets. Modern Internet cafés operate in renovated colonial buildings. And teenage girls promenade in historic plazas wearing cheap copies of exclusive designer fashions.

Sobral classifies 25 as a "very high endemic" area for Hansen's disease with a 2002 prevalence rate of 12.7 cases per 10,000 inhabitants, of which $85 \%$ represent the severely deforming multibacillary form. And leprosy rates are rising: from 1997 to 2002, the detection rate increased from 7.6/10,000 inhabitants to $11.4 / 10,000$ inhabitants and the prevalence rate increased from $8.9 / 10,000$ inhabitants to $12.7 / 10,000$ inhabitants 25. In 2002 alone, 205 active and 184 new cases were registered 25 , despite a $30 \%$ increase in primary health care coverage 25 and the implementation of a Special Task Force for the Elimination of Leprosy. Prior to 1997, health care was provided at social security clinics, located in public elementary schools 22; referrals from Sobral, and 25 surrounding counties, were sent to a single, under-staffed clinic. In 1999, services were decentralized to family health units and a dermatological reference service was opened 22 . The community was mobilized by organizing a self-help group (MORHAN - Movimento de Reintegração de Pessoas Atingidas pela Hanseníase), training traditional healers and sex workers to diagnose and refer suspected cases, and publicly awarding "certificates of cure" to patients adhering to treatment. Regardless, the notion that disease is fundamentally a biological phenomenon 20 , maintains a stronghold amongst health professionals in Sobral.

\section{Contextualized semantic interpretation}

From March 2003 to January 2006, this anthropological study explored the subjective dimensions of Hansen's disease. Of the 329 active cases of Hansen's disease being treated at two public clinics providing services in Sobral (FHP and County's Public Health Dermatology Referral Unit) in June 2003, 279 patients with confirmed multibacillary Hansen's disease were identified. After reviewing cases, a key-informant (ex-patient, MORHAN organizer) was invited to select six information-rich cases 26 known by the community activist to present either: (1) marked social suffering or (2) stigamatizing experiences for our in-depth ethnographic investigation. All six patients' illness narratives 27 were elicited during clinic visits, yielding a dense description 28 of leprosy discourse and experience. Seven follow-up home visits (one repeat) were conducted; relevant comments by patients' family members, neighbors, community health workers and healers were also recorded. Patients were observed during a follow-up consult with their attending physician; 28 additional consultations of these doctors with other leprosy patients were made, totaling 34 observations at the two health centers. A semi-structured interview, with four openedended questions about leprosy treatment, was conducted with the six physicians. Other key informants questioned included two nurses, three health practitioners, two dermatologists, clinic staff, authorities from the Ministry of Health and members of MORHAN.

Interviews were tape-recorded and transcribed verbatim utilizing a word processing computer program. After repeated readings of the transcriptions, 36 topics emerged, condensed into eight themes: (1) denial ofleprosy, (2) social suffering, (3) physical and social disabilities, (4) everyday coping strategies, (5) lay care practices, (6) clinical approaches, (7) patient-treatment approaches and (8) health education interventions. We sought inspiration in Bibeau \& Corin's 29 "contextualized semantic interpretation" to link individual experience with systems of significance and to actions taken, or not, within existing structural constraints. Qualitative data analysis aimed to make explicit the multiple interpretive frames and discourses (the "heteroglossia" 20) of leprosy, 
including contested interpretations by medical professionals. Core cultural symbols and illness metaphors were interpreted against a backdrop of current events published in Brazilian newspapers, magazines (Diário do Nordeste, O Povo, Veja) and drug advertisements and announced at public events and political rallies. The final text prioritizes the popular word lepra (leprosy) over the technical term, Hansen's disease, reflecting informants' discourse. Research adheres to the Brazilian Council of Bioethics in Health Research Involving Human Subjects Resolution $n^{o}$. 196/96. All informants' names are fictitious.

\section{Results}

\section{Stigmatizing leprosy metaphors}

Health professionals' hegemonic, technical discourse about Hansen's disease is often absent, contested or even subverted by Cearense (inhabitants of the state of Ceará) patients' narratives about lepra. Popular illness stories are loaded with cultural significance and embedded in the local moral world 4 and socio-political context of Northeast Brazil. In the individuality of informants' voices, and during dialogues with spouses, relatives, neighbors, colleagues, community health workers and medical professionals, four leprosy-related metaphors emerged. The first two metaphors - the rat's disease and a racist skin rash - we interpret with deeper insight. The second two - a Biblical punishment and lethal leukemia - are punctuated with spaces and blanks in meaning. It is clear, however, that all four metaphoric associations are pejorative, degrading and humiliating, capable of disfiguring not only patients' limbs but their moral reputations.

\section{Roberto: repulsive rat's disease}

Leprosy is interpreted as the "rat's disease", as leptospirosis is popularly called. The semantic link between a filthy rat and a patient's reputation became apparent from Roberto's narrative.

Roberto was 22-years-old when diagnosed with Hansen's disease, never suspecting that it was leprosy: "I wasn't afraid to tell anyone I was a Hansen's disease carrier (...) I didn't know it carried, well, such a heavy weight of prejudice (...) since I didn't pay much attention to what the doctor said!". Eating lunch with co-workers, Roberto casually downed his pills with a glass of water "in front of everyone in the world". But when he naively said the medication was to treat his Hansen's disease, everyone backed-off. Startled, one bystander yelled out: "Hey, stay clear folks
(...) stand back (...) because this rat's disease is contagious!". Roberto stood frozen in silence and shame. Later he commented: "It was at that moment I realized that, in reality, Hansen's disease is called (...) prejudice!".

Before this shameful cafeteria scene, Roberto believed leprosy was an innocuous, curable disease. His doctor reinforced this perception at diagnosis: "Roberto, from this day on, we are going to be friends. I'm going to see you cured. Don't worry (...) you needn't say anything about this to anyone either. This is a simple disease". This "simple disease", as it turned out, was rat infested! Hansen's disease was called the doença de rato (rat's disease), we suspect, because of the phonetic proximity of Portuguese terms lepra (leprosy) and leptospirose pronounced popularly as lepra-spirose. Through a semantic slip, the entirely distinct infectious disease - leptospirosis - caused by the microorganism Leptospira interrogans and transmitted by the common household rat is fused (and confused) with lepra (leprosy) and, consequently, with Hansen's disease. Transfiguring lepto-spirose into lepra-spirose instantly magnifies the microscopic $M$. leprae into a life-size rat.

In Northeast Brazil, the rat's reputation is morally suspect. Brazilians personify the rat - the guabiru or rabo-de-couro (leather tail), as an unsavory, garbage-eating rodent. For Claudio, 67, rats are synonymous with corrupt politicians: "The biggest thief of all is the rat, the guabiru, the rabode-couro! (...) Doesn't he sneak into your house and steal everything (...) the cheese? The same is true with corrupt politicians. Just like the guabiru, they steal half the public's money (...) stuff it into their own pockets (...) and nobody catches them because of their impunity!".

Newspaper headlines on December 17,2003 30 read "Saddam Hussein Captured in Iraq Inside a Hole". The sensationalist article described the US Army-backed search and capture of Iraq's dethroned leader, Sadam Hussain. "He was caught like a rat!" exclaimed the military commander. A humiliating photograph of a disheveled, longhaired and bearded Saddam and a diagram of his "underground" hide-a-way - a rodent's burrow - accompanied the report. A cover photo on Veja magazine 31 dated May 25, 2005 depicted a corrupt Brazilian politician personified as a rat (Figure 1). The man-size, hairy rodent is dressed in a business suit and tie, sports a shiny gold ring on his little finger and is smoking a large cigar-symbols of money, power and prestige. The caption in red capitals reads: "THE CORRUPT ONES". The suggestive subtitle adds: "We're Losing the War Against this Plague". The news-breaking story 31 uncovers the latest political corruption scandal 
Figure 1

Corrupt Brazilian politician personified as a rat. Cover photo on Veja magazine dated May 25, 2005

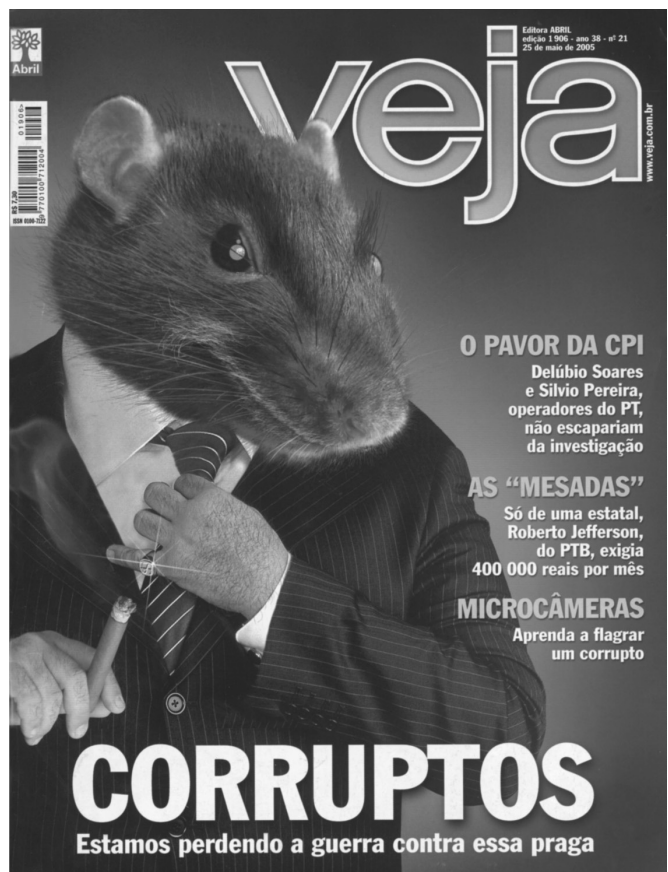

"THE CORRUPT ONES! We're losing the war against this plague".

to rock Brazil. Leaders of the President's ruling Workers' Party (PT) are accused of embezzling large sums of government money in a "monthly allowance" (mensalão) scam. A follow-up Veja cover on August 15, 2006 32, reprinted the rat-ascorrupt-politician photo denouncing another corruption scandal. The caption reads: "12 Ways to Stop Politicians from Stealing So Much”. The photo also depicts an oversized, wooden rat-trap loaded with bate - a seductive hunk of cheese molded in an upside-down, half-dome and pillar (a replica of the Brazilian National Congressional Building) - the seat of political power, money and influence. The article 32 (p. 43) reads: "The National Congress reached rock-bottom with the worst moral crisis in its 180 year history. After the scandalous episodes of the Worker's Party's (PT's) 'monthly allowance' and Serverino's 'little allowance' (another political scandal), federal Deputies and Senators were caught-up in the bloodsuckers' (Sanguessugas) mafia - a chain of direct assaults on public funds, reaching startling dimensions as each day passes". The text reports on the "shocking degree of corruption" among Brazil's highest level government officials and suggests ways to "trap the corrupt ones!" Veja's 33 cover photo of August 15, 2007 depicts the rat-as-corrupt-politician behind prison bars, symbolizing "the plague of impunity". Semantic webs of meaning couple the rat's immoral image with the rat's disease, infectious lepto-spirose, lepra-spirose and leprosy. Through metaphoric associations, innocent $M$. leprae-infected persons become thieves, who deserve to be "trapped" by prejudice.

\section{Marcos: racist skin rash}

Leprosy is also perceived as a racist skin rash. Clofazimine, a reddish-brown, microcrystalline powder, is one of three drugs used in the powerful multi-drug therapy. While Clofazimine exerts a slow bacterial effect on $M$. leprea, $77.8 \%$ of 514 treated patients experienced red and dark skin pigmentation of varying intensity 34 ; reddish coloration of sweat, urine and tears also occurs. Although the drug's instructional insert downplays skin discoloration, it warns that adverse effect may last for months, even years, after cessation of therapy, cause depression and confirms two associated suicides (NOVARTIS. Lamprene (clofazimine) soft gelatin capsules: prescribing information. http://www.pharma.us.novartis. com/product/pi/pdf/lamprene.pdf, accessed on 02/Feb/2008). Even the World Health Organization (WHO) 35 declares that discoloration is not a serious problem, except for being "cosmetically unacceptable to some patients".

Nazaré, a 38-year-old domestic maid, contests these claims, reporting that skin-darkening Clofazimine contributes to color prejudice: “ $M y$ uncle was 'moreno claro' [a person with lighter, bronzed-colored skin tones] before he started taking those pills [Clofazimine] (...) but afterwards he turned that dark (...) dark (...) dark (...) almost that purple-black color. What an awful thing, God forbid!". Racial issues relating to the use of Clofazimine surfaced during this clinical conversation between Marcos, 54, and his physician:

Doctor: "This is the medication you must take (...) both these black and white pills".

Marcos: "Am I going to turn dark-skinned with this treatment? What is this business anyway?".

Doctor: "No, the skin darkening is just temporary. Afterwards, with time, it will get better (...) fade away. There are ways to minimize this".

Marcos: "Doc, if it's going to mess up my body, don't prescribe these pills, no! I've heard that there's two kinds of pills - just the little white one alone (...) and the little white pill together with the little black one (...) don't give me that one, no way! I don't want to become a 'nigger' [negão], no way! Before, I was only a leper. But now, I'm going to be a nigger leper [leproso negão]!". 
Ingesting this "dark skin pill" transforms a bronzed-colored moreno into a dark-skinned "negão", (sometimes) loosely translated as "nigger”. Drug-induced skin coloration binds with pre-existing color prejudice to stigmatize patients. Although the pigmentation is usually reversible after 9-12 months, it is sufficient time to suffer racism. Patients beg doctors not to prescribe the "little black pills" (Clofazimine) and skip over the rows of dark pills on the multi-drug aluminum pill card. They prefer taking only the "little white ones". For Marcos, becoming a "nigger leper" is doubly discriminating. In Brazil, where ethnic origins (Afro-Brazilian) become confused with "race" and "race" becomes identified as phenotype, racism takes on a distinctive characteristic: it is tied to infinite shades of skin color. Brazilian anthropologist Ribeiro ${ }^{36}$ (p. 225) clarifies: “... on this scale, the negro (black) is the negro retinto ('deep' black), the mulatto is the pardo (half white), and if his skin is a little bit lighter, he can already be incorporated into the white community".

The persistence of institutionalized racist attitudes and policies in Brazil, however, defies the popular myth that Brazilians of diverse colors and ethnicities live harmoniously as one people 36 . The truth is that the life-expectancy of AfroBrazilians is lower than that of their white compatriots 37 , and indigenous populations suffer the poorest health indicators in the country 38 , amongst other inequities. Lighter skin shades, however, generally confer higher social rank; while darker epidermis denotes lower status. In status-conscious Sobral, light skin indicates nobel European heritage; darker tones are associated with (forcibly) enslaved Tupi-Guarani and African people, treated, historically, as inferior 21. Leprosy patients, like Marcos, skip taking Clofazimine pills to avoid color prejudice and social enslavement.

\section{Marta: Biblical curse}

Since Biblical times, leprosy has signified more than disease. It is a "metaphor for evil" associated with notions of falling body parts, sin, transgression of social norms, and banishment ${ }^{39}$. Israelites designated the person with "malignant sores" as tsara'ath, a Hebrew word for a state of religious impurity, translated into Greek as "leprosy" 39. Over time, lepra came to stand for all social or moral wrongs of society, including sexual impropriety. Marta, a 40 year old, Catholic woman "without family", never married. She admits to causal sex with numerous men - a source of gossip among neighbors. Undergoing her sixth dose of multi-drug therapy and suffering reac- tions, Marta recalls her colleagues' social shunning and her attempted suicide: "I was diagnosed during a screening at my work (...) I almost died (...) I never thought I'd have this disease! (...) The doctor said it was Hansen's disease (...) but I heard his nurse say 'leprosy!'” (grifo nosso). Stunned she was "a leper", Marta felt as if her "head was tied in knots!". She worried incessantly: "Isn't leprosy that ancient Biblical curse (...) where your fingers fall off?". Colleagues pester her: "What's-yourname, do you really have leprosy?". A co-worker separated his cup from Marta's. "He was trying to say something to me!". Distraught, she "took a medicine to die!". Marta slowly "grew to accept that I have leprosy". She avoids saying "leprosy", affirming: "What I have is Hansen's disease!". Despite supportive friends, she feels alone and depressed without a husband or children. On weekends, Marta drowns her sorrows by drinking.

Marta's painful stigma is amplified by her religious beliefs and certainty that Hansen's disease is leprosy. She read us a Bible 40 verse about Satan inflicting a curse of ugly sores: "So Satan went out from the presence of the Lord, and struck Job with painful sores from the sole of his foot to the crown of his head" 40 (Job 2:7). Marta then turned to the Old Testament Book of Leviticus and "the law of the leperous plague" 40 (Lev 13:2:59): "The priest shall examine the sore on the skin of the body (...) if it is a leprous sore, he shall pronounce the man unclean...his clothes shall be torn and his head bare (...) shall cryout, 'Unclean, unclean!'. He shall dwell alone (...) outside the camp (...) you shall burn with fire that in which is the plague" 40 (Lev 13:1-3, $45,57)$. Deeply ashamed, Marta isolates herself and drinks excessively, preferring to speak of the less morally-incriminating Hansen's disease.

\section{Joel: lethal leukemia}

The final metaphoric association - leprosy as lethal leukemia - is speculative but helps explain Joel's vehement denial of hansemia - a curious, "made-up" word we frequently heard in the clinic.

Joel, a 21-years-old laborer, is an M. leprae carrier who abandoned treatment, as did his uncle and older brother, Elias. Joel believes "nothing is wrong" with him: "I'm as good as can be (...) only these white skin patches [pano branco]". Ten years earlier, "the doctor said I had this disease (...) hansemia" and prescribed pills, but Joel refused to take them: "They made me sicker and laid me up (...) unable to work". He dismissed symptoms - white spots, loss of eyebrow hair, saddle nose, flaky, dry skin, claw hands, and scars on the hands, legs and feet - as childhood problems. "See this thing on my forehead and this here on my nose? I've had these since infancy! This scar on 
my left hand is a burn (...) I burned my hand and it stayed like this!". And he blamed the skin spots on "sun exposure", contact with "hospital filth" and "eating very salty foods". While his brother - "totally done in by hansemia" - quit work, abandoned wedding plans and contemplated "doing a stupid thing [committing suicide]", Joel "enjoys life to its fullest!".

For years, Joel has disguised his white spots as pano branco ("white patch"), the innocuous fungal skin infection, Pityriasis Versicolor. To escape his hansemia he struggles to lead a normal life. From dawn to dusk, this sturdy man shovels and hauls heavy buckets of wet sand from the banks of the Acaraú River in Ceará State. His young wife admires Joel's vitality, strength and endurance, bragging that he is "a good provider (...) a family man". In his neighborhood, laboring hard to support one's family is a core masculine value - at the heart of being macho (manly) in Ceará's rugged sertão.

Joel abandoned care after a nurse visited his workplace, scolding him in front of co-workers for not "admitting his disease" or "taking his medication". Although vowing to "help when he is too crippled to work" she embarrassed and stigmatized him as a "useless creature". While the word hansemia is inexistent in formal Portuguese, in popular discourse the first syllable of hans-eníase (Hansen's disease) is grafted onto the ending of leuc-emia (leukemia), forming the hybrid: hansemia. The grammatical merger symbolically transforms treatable Hansen's disease into a lethal "blood disease" - leukemia. Similarities between the two distinct diseases are blurred together. Hansen's disease's "malignant sores", "dormant white spots", "falling fingers" and "poliquemioterapia" (multi-drug therapy) are confused with cancer's "malignant tumors", "white blood" (Greek root of the word, leukemia), "hair-falling-out" and "quimoterapia", respectively. As a dreaded, cancer-like disease, hansemia radically contests physicians' discourse that "Hansen's disease has a cure!". Terrified patients refuse to say the name of "that disease": cancer. Others complain that hansemia is "turning my blood into water (...) eating me up from the inside!". By rejecting the grave "blood cancer" diagnosis and fatal prognosis ("death sentence"), Joel continues to work, provide for his family and safeguard his reputation as a man.

\section{"Skin Spot Day": educate or discriminate?}

After the Brazilian Ministry of Health transformed the feared lepra into curable Hansen's disease, the priority became early disease detection by heightening public awareness of symp- toms. Sobral's health workers distributed pamphlets teaching low-literacy residents how to distinguish simple dermatitis - rashes, irritations, pussy sores, nodules and infiltrations - from white, dormant leprosy lesions. Color photos of the two types of skin lesions were pictured sideby-side for easy comparison. "Skin Spot Day" (Dia da Mancha) was designated as a monthly massive-screening event to be held at Sobral's six family health clinics. Medical staff aimed to examine large numbers of autonomous, walk-in residents quickly and free-of-charge. Suspected cases of Hansen's disease would then be referred for intensive medical follow-up. Our observation of "Skin Spot Day" held on May 14, 2004, however, revealed that the clinic nurse's role of screening the general population for disease had been transformed into a stigmatizing event, as this field note excerpt illustrates:

"At 7:30 am, a line formed outside the clinic for spot screening scheduled to begin at 8:00 am. A poster on the wall read: 'Dormant spots can be Hansen's disease (...) Hansen's disease has a cure'. By 9:30a.m. no spots had been examined. When the nurse finally arrived, seven weary individuals - including two of our informants - were ushered into a large room. Rather than efficiently examining skin spots as I had expected, the nurse greeted and embraced each 'autonomous' person by name, clearly indicating she knew them personally. The 'residents' quickly fell out of line, taking their customary seats in a circle of pre-arranged chairs. The nurse addressed the group announcing that the aim of this 'monthly meeting' was 'to hear the patient', 'clarify his doubts about the disease and treatment', 'to avoid abandonment of therapy' and 'to better integrate patients with professionals'”.

Unwittingly, the nurse (and clinic staff) had transformed the widely advertised "Skin Spot Day" into a highly-visible stigma fair. On the broadcasted day, May 14, any neighbor could gaze out of their front window and see seven "spotted lepers" lined-up outside the clinic. When she replaced the screening of Sobral's 200,000 nameless residents with a small, personalized, self-care gathering, it became easy for anyone to identify the town's "lepers", tainting their reputations. Locals with suspicious white spots, it was rumored, avoided the clinic on "Skin Spot Day" so as not to be mistaken for a leper. Discrimination, not education, marked this special day.

\section{Discussion}

This anthropological interpretation uncovers experiences of stigma narrated by patients 
with severely disfiguring multibacillary Hansen's disease in Northeast Brazil. Through a litany of culturally-constructed illness metaphors - from sleazy rats to lethal leukemia - they voice stories of fears, rejection and indignation. These shared moral experiences of lepra are so troubling, as Kleinman ${ }^{4}$ says, precisely because what looks so unjust from patients' perspectives looks different from the vantage point of collaborators or perpetuators. Leprosy's webs of significance are embedded in our patients' symbolic universe and local moral world - the desert backlands of Sobral.

Two studies by Claro 12 and Oliveira et al. 10 in southern, industrialized Rio de Janeiro, clarify considerably the human dimensions of Hansen's disease. Limitations in their interpretative approaches, however, truncate their full explanatory power. Claro's 12 analysis of 45 patients' illness representations adheres to a biomedical framing of the disease (cause, treatment, adhesion), distorting subjective constructions. Oliveira's et al. 10 free-word-association test of 800 housewives, speculates that "the word 'rat' could be related to leprosy" 10 (p. 44) but does not explore the association further. By penetrating into the rich semantic world 20 of $M$. leprae-affected patients in Brazil's Northeast, this study makes an original contribution to the new science of stigma.

Bibeau \& Corins 29 "contextualized semantic interpretation" was a fortunate methodological choice. It challenged us to cross-cut symbolic, behavioral, social, political and economic dimensions of patients' lifeworlds. Interpreting the meaning of the "rat's disease" demanded considering the guabiru's corrupt image. Marta's shame and suicide attempt only made sense in light of her sexual history and the Bible's Leprosy Law. Embedding semantic analysis in the macrosociological context illuminates cultural interpretations and avoids victim-blaming ${ }^{3}$. What matters in this critical analysis, is situating Hansen's disease squarely within "The-United-States-of-Sobral" - a poor, but pretentious, town with a distinctive nobel heritage and haughty First World reputation. This is the local moral world of crippling, endemic leprosy stigma.

Findings not only corroborate Mull et al.'s 5 conclusion of “'non-compliance' to the stigma attached to 'lepers'..." 5 (p. 805), it makes explicit the metaphoric associations linking Clofazimine "non-adherence" to dark pills, hyperpigmentation, Brazilian race/ethnic classification and color prejudice. Although the drug's adverse effect is temporary, and downplayed by drug manufactuers (NOVARTIS. Lamprene (clofazimine) soft gelatin capsules: prescribing information. http://www.pharma.us.novartis. com/product/pi/pdf/lamprene.pdf, accessed on $02 / \mathrm{Feb} / 2008$ ), it provokes patients' fears of color discrimination. Meanwhile, the recent, dramatic case of argyria 41 in an American man, 57 - irrevocably turning his fair skin dark, bluepurple after ingesting colloidal silver, a popular cure-all - has stirred attention ${ }^{42}$. Marcos, like the "blue man", suffers stigma, isolation and social shunning.

In “The-United-States-of-Sobral”, institutionalized discrimination 16 occurs when clinic staff publicly scrutinize identifiable patients' skin spots. While health professionals, elsewhere, reportedly harass, spread rumors, and refuse to treat leprosy patients 43 , they have been shown to reduce discrimination 44 by increasing diseaserelated knowledge 6 , engaging community members 6 , improving access to therapy ${ }^{5}$, providing group counseling 17 , adopting a culture-sensitive paradigm 39 , and reducing poverty 45 .

Our ethnographic evidence confirms that stigmatization is a deeply moral experience 4 , expressed in a multiplicity of voices, sculpted by context and contested by hegemonic medical discourse and practice. A critical evaluation of Sobral's spot-detection-day demonstrates that improved access to services, alone, does not reduce leprosy stigma. What really matters is providing quality, non-accusatory care which empowers citizens and promotes human dignity.

\section{Conclusions}

\section{Stigma: social leprosy of modern times}

“We're all lepers!" shouts ex-patient, Jeremias, at a MOHAN rally. His protest cry is a potent reminder that leprosy stigma wounds moral reputations as much as mircroorganisms destroy connective tissue. Lepra is interpreted in culturally-contextualized ways, expressed through illness metaphors, and morally experienced in infinite ways. "Multiple-stigma” is resistant to standardized eradication efforts. Eliminating prejudice, re-moralizing affected-persons, and empowering patients to defend their rights is as critical as lowering $M$. leprae counts in their bloodstream.

Social injustice is not restricted to leprosy or to Northeast Brazil. It emerges when structural constraints channel the way we organize society, establish patterns of interaction and rank, value, and esteem one individual over another. Anyone suffering from stigma - the plague of modernity - is crippled by a kind of "social leprosy", robbing them of their human potential. All forms of discrimination must be denounced if social leprosy is to be eradicated. 


\section{Resumo}

No intuito de criar uma Ciência do Estigma, este estudo antropológico investiga a experiência moral de pacientes diagnosticados com a hanseníase multibacilar. De 2003 a 2006, a pesquisa foi conduzida nos "Estados Unidos do Sobral", Estado do Ceará, Brasil, altamente endêmico para hanseníase apesar da intensificação de erradicação e o aumento de $30 \%$ na cobertura de saúde desde 1999. Entre 329 casos de hanseníase, 279 foram identificados como multibacilar e seis casos "ricos em informação" foram selecionados para aprofundamento. Narrativas da enfermidade, entrevistas etnográficas, visitas domiciliares, observação-participante de consultas clínicas e entrevistas semi-estruturadas com médicos foram realizadas. A "interpretação semântica contextualizada" revelou quatro metáforas de "lepra" - uma repulsiva doença de rato, uma infecção de pele com conotações racistas, uma praga bíblica, e uma leucemia letal. Essas metáforas "multivocálicas" contestam o discurso biomédico. A lepra é repleta de significados morais. O "Dia da Mancha" descrimina mais do que educa. A falta de aderência à eficaz poliquimoterapia é causada mais pelo estigma desmoralizante do que pela rejeição ao tratamento em si. A "lepra social" no nordeste brasileiro deforma a reputação moral e a dignidade do paciente.

Hanseníase; Estereotipagem; Metáfora

\section{Contributors}

M. K. Nations participated in the research design, directed the data analysis and interpretation and wrote the article. G. V. Lira designed the research, collected data, participated in data analysis and interpretation and revised the text. A. M. F. Catrib designed the research and participated in the data analysis.

\section{Acknowledgments}

Financial support was provided by the Brazilian Council for Scientific and Technological Development (CNPq, project 403521/2004-1).

M. K. Nations was supported (2007-2008) in the Department of Global Health and Social Medicine, Harvard Medical School, Boston, MA, USA, by the CNPq (\# 210210/2006-0).

\section{References}

1. Keush GT, Wilentz J, Kleinman A. Stigma and global health: developing a research agenda. Lancet 2006; 367:525-7.

2. Castro A, Farmer P. Understanding and addressing AIDS-related stigma: from anthropological theory to clinical practice in Haiti. Am J Public Health 2005; 95:53-9.

3. Ryan W. Blaming the victim. New York: Parthenon Books; 1971.

4. Kleinman A. What really matters: living a moral life amidst uncertainty and danger. Oxford: Oxford University Press; 2006.

5. Mull DJ, Wood CS, Gans LP, Mull DS. Culture and "compliance" among leprosy patients in Pakistan. Soc Sci Med 1989; 29:799-811.

6. Berreman JM. Childhood leprosy and social response in South India. Soc Sci Med 1984; 19: 853-65.

7. Nations MK, Monte CMG. "I'm not dog, no!": cries of resistance against cholera control campaigns. Soc Sci Med 1996; 43:1007-24.

8. World Health Organization. The elimination of leprosy as a public health problem: status report 2001. Geneva: World Health Organization; 2002.

9. Kerr-Pontes LRS, Barreto MI, Evangelista CMN, Rodriques LC, Heukelbach J, Feldmeier H. Socioeconomic, environmental, and behavioural risk factors for leprosy in North-east Brazil: results of a case-control study. Int J Epidemiol 2006; 35: 9941000.

10. Oliveira MLW, Mendes CM, Tardin RT, Dunha MD, Arruda A. Social representation of Hansen's disease thirty years after the term "leprosy" was replaced in Brazil. Hist Ciênc Saúde-Manguinhos 2003; 10 Suppl 1:41-8.

11. Queiroz MS, Puntel MA. A endemia hansênica: uma perspectiva multidisciplinar. Rio de Janeiro: Editora Fiocruz; 1997.

12. Claro LBL. Hanseníase: representações sobre a doença. Rio de Janeiro: Editora Fiocruz; 1995.

13. Oliveira MHP, Romanelli G. Os efeitos de hanseníase em homens e mulheres: um estudo de gênero. Cad Saúde Pública 1998; 14:51-60. 
14. Goffman E. Stigma: notes on the management of spoiled identity. Englewood Cliffs: Prentice-Hall; 1963.

15. Douglas M. Purity and danger: an analysis of concepts of pollution and taboo. London: Routledge; 1966.

16. Lee SC, Chiu MYL, Tsang A, Chui H, Kleinman A. Stigmatizing experience and structural discrimination associated with the treatment of schizophrenia in Hong Kong. Soc Sci Med 2006; 62: 1685-96.

17. Floyd-Richard M, Gurung S. Stigma reduction through group counseling of persons affected by leprosy: a pilot study. Lepr Rev 2000; 71:499-504.

18. Tsutsumi A, Izutsu T, Akramul MD, Amad JU, Nakahara S, Takagi F, et al. Depressive status of leprosy patients in Bangladesh: association with selfperception of stigma. Lepr Rev 2004; 75:57-66.

19. Opala J, Boillot F. Leprosy among the Limba: illness and healing in the context of worldview. Soc Sci Med 1996; 42:3-19.

20. Good BJ. Medicine, rationality and experience: an anthropological perspective. Shaftesbury Road: Cambridge University Press; 1994.

21. Freitas NA. Sobral: opulência e tradição. Sobral: Edições UVA; 2000.

22. Andrade LOM, Martins-Júnior T. Saúde da família: construindo um novo modelo: a experiência de Sobral. Sanare (Sobral) 1999; 1:7-17.

23. Assassinato em Sobral-CE. http://violenciabrasill. spaceblog.com.br/21018/ASSASSINATO (accessed on 02/Feb/2008).

24. Faheina R. Assassinato de mulheres: números crescem no Cariri Ceará. http://www.opovo.com. br/opovo/ceara/594258.html (accessed on 02/ Feb/2008).

25. Conselho Nacional de Secretarias Municipais de Saúde. Estratégia de aceleração da eliminação da hanseníase em todos os municípios do Brasil. Brasília: Conselho Nacional de Secretarias Municipais de Saúde; 2000.

26. Yin RK. Estudo de caso: planejamento e métodos. 2a Ed. Porto Alegre: Bookman; 2001.

27. Kleinman A. The illness narratives. New York: Basic Books; 1988.

28. Geertz C. A interpretação das culturas. Rio de Janeiro: Editora Guanabara Koogan; 1989.

29. Bibeau G, Corin EE. From submission to the text to interpretive violence. In: Bibeau G, Corin EE, editors. Beyond textuality: asceticism and violence in anthropological interpretation. Berlin: Mouton de Gruyter; 1995. p. 3-54. (Approaches to Semiotics).
30. Saddam Hussein preso no Iraque dentro de buraco. Diário do Nordeste 2003; 15 dez.

31. Carneiro M, Linhares J. Temporada de caça de ratos. Revista Veja 2005; 25 may.

32. Escosteguy D. 12 ações para caçar os corruptos. Revista Veja 2006; 2 aug

33. A praga de impunidade: por que eles nao ficam presos. Revista Veja 2007; 15 aug.

34. Kumar B, Kaur S, Kaur I, Gangowar DN. More about clofazimine-3 years experience and review of literature. Indian J Lepr 1987; 59:63-74.

35. World Health Organization. WHO/MDT: side effects FAQ. http://www.who.int/lep/mdt/side_ef fects/en/indexl/html (accessed on 02/Feb/2008).

36. Ribeiro D. O povo brasileiro: a formação e o sentido do Brasil. 2a Ed. São Paulo: Editora Companhia das Letras; 1995.

37. Oliveira F. Saúde da população negra: Brasil - ano 2001. Brasília: Organização Pan-Americana da Saúde; 2002.

38. Coimbra Jr. CEA, Santos RV. Saúde, minorias e desigualdade: algumas teias de inter-relações, com ênfase nos povos indígenas no Brasil. Ciênc Saúde Coletiva 2000; 5:125-32.

39. Lira C, Catrib AMF, Nations MK, Lira RCM. A hanseníase como etno-enfermidade: em busca de um novo paradigma de cuidado. Hansen Int 2005; 30:185-94.

40. The Holy Bible. New King James version. Philadelphia: National Publishing Co.; 1985.

41. Man claims skin treatment turned face permanent blue. http://www.foxnews.com/story/ 0,2933,3175464,00.html (accessed on 02/Feb/ 2008).

42. Brandt D, Park B, Hoang M, Jacobe HT. Argyria secondary to ingestion of homemade silver solution. J Am Acad Dermatol 2005; 53(2 Suppl 1):S105-7.

43. Awofeso N. Appraisal of the knowledge and attitude of Nigerian nurses towards leprosy. Lepr Rev 1992; 63:169-72.

44. Awofeso N. Concept and impact of stigma on discrimination against leprosy sufferers: minimizing the harm. Lepr Rev 2005; 76:101-2.

45. Awofeso N. Potential impact of poverty alleviation activities on reducing leprosy transmission. Lepr Rev 2004; 75:196-8.

Submitted on 19/Sep/2007

Final version resubmitted on 12/Jun/2008

Approved on 12/Jun/2008 